\title{
Service Quality Level of Post Office Saving Bank: A Perspective from Customers and Employees
}

\author{
Sarang Narula, Priyanka Arora
}

\begin{abstract}
The study aims to analyze the level of service quality of Post office Saving Bank from perspectives of customers and employees both. In particular, the objective of the paper is to study major gap i.e. service quality gap and other gaps contributing to major gap i.e. understanding gap, internal evaluation gap and service delivery gap. Present research seeks to gain an empirical insight into customers' perceptions of service quality in Indian Postal Services. The target population of the survey was all the saving scheme users of Post Office saving Bank in Punjab state and all the employees working in POSB. For the purpose, the paper applies 'Simple random sampling technique' taking sample size of 200 customers and 100 employees. Data has been collected from various branches of 'India post' across State of Punjab. The relevant literature and instruments developed by past studies provided the base for developing research instrument. The study uses modified SERVQUAL with total of 35 items. For measuring mean differences, independent sample T-Test was used. The findings of the study revealed that service quality level of POSB was far below the expectations of customers. The service quality gap indicates that there were problems in understanding expectations of customers, making service standards and delivering service which collectively became the reason of this gap. The study will be extremely useful for the service providers and management as it pinpoints the areas of service shortfalls which need improvement. This paper develops a new model which consists of various service quality gaps causing major service quality gap. Considering the limitations of study, the paper also provides some directions for future scope of research in the same area as well as in other areas.
\end{abstract}

Keywords : Service Quality, SERVQUAL, Customers, Perceptions, Customers' Expectations, Employees' Perceptions and Employees' Perceptions of Customers' Expectations.

\section{INTRODUCTION}

This India is one of the rapidly growing economies of Asia. Emergence of several significant trends such as liberalization, globalization, demographics shifts towards urbanization and monetization of economy is giving rise to corresponding demand for financial services by all the sections of society. Moreover government policies are emphasizing financial institutions to increase funding for weaker section. This scenario has necessitated changes in financial framework of country (Aggarwal, 2012).

Revised Version Manuscript Received on 16 September, 2019.

* Correspondence Author

Dr. Sarang Narula, Assistant professor, University School of Applied Management, Punjabi University, Patiala, Punjab

Priyanka Arora, Research Scholar, University School of Applied Management, Punjabi University, Patiala, Punjab
During the past two and a half decades, many regulatory, organisational, structural, and technological reforms have taken place which contributed to significant changes in the financial services marketing environment in the US as well as around the world (Angur et al., 1999). Financial liberalization is leading to intense competitive pressures. In current era, every organisation wants to strive for excellence and there are so many factors which contribute for excellence of an organisation. Many Service providers seek to differentiate themselves by providing quality service and ensuring satisfaction of customers. So, quality has been found to be the most significant factor for attracting as well as maintaining customer (Bharwana et al., 2013; Naik et al., 2010). Therefore, companies are consequently directing their strategies towards increasing service quality level which fosters customer satisfaction and loyalty through improved service quality. It is becoming an increasingly important factor and a pre-requisite for economic performance in every service industry. Brown and Swartz (1989) argues that consistent delivery of superior service is the only strategy that can be offered as a key to success by service providers to position themselves more effectively in the market place. Financial services providers need to struggle to distinguish themselves from the competitors as customers perceive very little difference in the products offered by financial service providers and any new offering is quickly matched by competitors. In order to excel in the market, a service provider must first identify the service quality dimensions which a consumer analyses to evaluate overall service quality.

Also, investment culture among the people of India is increasing day by day. Earlier only banks were dominating the market where people used to put their extra money as a saving. Later on, so many financial institutions entered in the market to attract savings of people. Many of them are attracting investors with better returns, high quality IT related services, tax savings and much more benefits. At one place where large bundle of financial products with differential advantages is being offered in the market, Indian Government is still sustaining the oldest institution to save money i.e post offices. It is emerging as an integral part of the economy by competing with banks and other financial service providers in terms of attracting small saving schemes users.

Further, it is a matter of concern whether customers are still preferring to opt post office saving bank where so many private players are there in competition as it is also observed from literature that in spite of development of POSB, 
standard and quality of service provided by this bank is far below as compared to banking sector of economy. Present research seeks to gain an empirical insight into customers' perceptions of service quality in Indian Postal Services. This study investigates how POSB (Post Office Saving Bank) performs in terms of the service quality and which service quality dimensions are more significant in achieving service quality. The research mainly focuses on analyzing the gap between customer's service expectations and perceptions of actual service delivered by the service providers and further coming up with the factors contributing for the service quality gap by identifying other gaps. By analyzing the gap between customers' expectations and perceptions of service quality, an attempt is made to make this study helpful to management to confront with service quality deficiencies and areas of dissatisfaction with opportunities to improve overall service quality performance.

\section{THEORETICAL FRAMEWORK}

\section{Service Quality}

Quality is regarded as the most important consideration for customer whether it is of the product or the service. It is degree of excellence i.e. the extent to which something is fit for the purpose. Various studies conducted on quality clearly demonstrate that it is an important tool for marketers to excel in the market for improving productivity, efficiency, market share and return on investment. Providing high quality service goes a long way for the success of business. It is regarded as critical factor to the survival as well as profitability of business. Also it is the factor which investigates the outcome of customer's perceived attributes as perception regarding service quality has both positive and negative effect on business and attitude of customers. Service quality is a concept that has aroused considerable interest and debate in the research literature because of the difficulties in both defining it and measuring it with no overall consensus emerging on either (Wisniewski, 2001). There are number of different "definitions" as to what is meant by service quality. One that is commonly used defines service quality as the extent to which a service meets customers' needs or expectations (Lewis and Mitchell, 1990; Dotchin and Oakland, 1994, Asubonteng et al., 1996; Wisniewski and Donnelly, 1996).

\section{MEASUREMENT OF SERVICE QUALITY}

As discussed above, quality has been conceptualized differently by differently authors and on the basis of these conceptualizations, alternative scales have been developed to measure service quality. Out of alternative scales, SERVQUAL and SERVPERF has been used by most of the researchers. However no consensus is found anywhere regarding which scale is better for measuring service quality. The most used measurement scale is SERVQUAL given by PZB (1988). The most used measurement scale is SERVQUAL given by PZB(1988). It measures service quality based on five dimensions i.e. Tangibility, Reliability, Responsiveness, Assurance and Empathy. The scale has two aspects: Expectations and perceptions. Expectations part measures customers' expectations regarding service based on these five dimensions and perceptions part measures customers' actual perceptions regarding service after availing particular service. This scale finally measures the gap between customers 'expectations and perceptions. These gaps indicate the efficiency and inefficiency on the part of service providers regarding different dimensions of service quality. When perceived service is found to be greater than the expected service, this indicates (+) gap i.e. Satisfaction of consumer and when perceived service is found to be less than the expected service, this indicates negative gap thereby implying that customer is dissatisfied for that particular service. So SERVQUAL by measuring disconfirmation or gap not only indicates service provider's ability to provide quality service, it also becomes the basis to decide the satisfaction level of customer regarding a particular service.

\section{LiterATURE REVIEW}

Gronroos (1984) found in his model named Nordic model that for assessing service quality of an organisation, the customer considers three components of service quality namely: technical quality, functional quality and image. Technical quality is the quality which a consumer actually receives as a result of his/her interaction with the firm. Functional quality is how a consumer gets the technical outcome. The third component 'image' is very important which depends upon technical and functional quality of service including the other factors such as ideology, word of mouth, pricing and public relations.

Zeithmal et al. (1988) conducted an exploratory study by taking interviews of executives of service firms to see the impact of four gaps of service quality (knowledge gap, service design gap, service delivery gap, external communication gap) on fifth gap (service quality gap) and identified that extent of service quality gap .i.e. difference between customer perception and expectation depends upon the extent of four gaps on marketer's side in service quality model. All the four gaps were taken as independent variable and service quality gap as dependent variable. The study came out with factors affecting the magnitude and direction of four gaps which ultimately affect the fifth gap i.e. service quality gap and concluded with a detailed conceptual explication of service quality model i.e. extended model of service quality with all the factors responsible for all the gaps that can be used as a blueprint for developing measures of gaps.

Tsang and qu (2000) used gap model of service quality in Hotel industry to measure gap between tourists' expectation and their actual perception, between manager's perception of tourists' expectations and their actual expectations, between managers' perceptions of Hotel's service delivery and tourists 'actual perceptions and between managers' perceptions of tourists' expectations and their own perceptions of actual service delivery. A structured questionnaire was used taking sample of 90 managers and 270 tourists. Descriptive analysis, paired t-test and independent t-test were used to investigate the gaps. Results of the study showed that tourists' perceptions were lower than their expectations and managers were too self assured about service delivery. From the results of gap analysis it was concluded that delivery gap and internal evaluation gap were the main reasons contributing to service quality shortfalls. Therefore indentifying these gaps can provide management with a clear direction on how to address service quality 
shortfalls in the hotel industry in China.

Mukherjee et al. (2003) formulated a model for measuring efficiency of banking services taking service quality as an independent variable and further measuring service quality taking resources as an independent variable thereby linking marketing variables to financial metrics. The impact of service quality on efficiency was verified using efficiency matrix. It was found that banks delivering better service were shown to have better transformation of resource to performance using service quality as medium. Thus the model R-SQ-P showed significant impact of resources on service quality and further service quality on performance by taking two stages service and efficiency measurement for Indian banks as shown below. service quality models in four groups. First reviewed model was of Gronroos(1984) having technical and functional quality as the features and Phillip and Hazlett(1997) having pivot, core and peripheral quality. Second reviewed model was PZB's GAP model(1985) with SERVQUAl measure which consisted five dimensions: Tangibility, reliability, assurance ,empathy and responsiveness. The third model was Dabholkar et al' $\mathrm{s}$ retail service quality model having basic five dimensions i.e. Physical aspects, Reliability, Personal interaction, Problem solving, and Policy. The fourth model was Brady and Cronin's Service Quality Model (2001) which consisted SERVPERF dimensions such as Personal interaction quality, Physical service environment quality and Outcome quality. The outcome of the study revealed that Servqual was found be the most used measure by service sector. The study also highlighted the requirement of all the $7 \mathrm{p}$ 's of service marketing mix.

Handrinos et al. (2015) undertook a study to measure the service quality of SME (Small-Medium Enterprise) of a farm school. Servqual was applied as a means for measuring service quality having different dimensions from the original one as shown below in figure 7 and results showed that security, empathy and reliability were the significant dimensions for customers.

\section{GAP MODEL}

From the result of the research conducted in the companies of four different service sectors: banking, telecommunications, insurance companies and repair and maintenance of appliances, Parasuraman, Zeithaml and Berry developed a GAP model which measures 'gaps' between service quality expectations before availing the service and perceptions regarding service quality after the service process. The same authors developed a measurement tool for measuring the service quality - SERVQUAL which consisted of five quality determinants (tangibility, reliability, responsiveness, model as well meets criticism when observed form conceptual and methodological aspect (Asubonteng et al., 1996). It is capable of assisting the management to identifyrelevant service quality factors from the viewpoint of the consumer (Seth et al. 2005). This model demonstrates the process of the development of the service quality.

The model was presented for the first time in 1985, when the service quality was defined as a difference between the way how a costumer experienced a service (perception) and
Yarimoglu (2014) conducted a review study by studying the assurance and empathy) with 22 questions. However, the

expectations which a customer created before using the service. Oversights, i.e. variations in the process of service offer according to this model in the form of five major gaps are as follows: (Parasuraman et al., 1985).

Gap1: Customers' expectations versus management perceptions: as a result of the lack of a marketing research orientation, inadequate upward communication and too many layers of management.

Gap2: Management perceptions versus service specifications: as a result of inadequate commitment to service quality, a perception of unfeasibility, inadequate task standardisation and an absence of goal setting.

Gap3: Service specifications versus service delivery: as a result of role ambiguity and conflict, poor employee-job fit and poor technology-job fit, inappropriate supervisory control systems, lack of perceived control and lack of teamwork.

Gap4: Service delivery versus external communication: as a result of inadequate horizontal communications and propensity to over-promise.

Gap5: The discrepancy between customer expectations and their perceptions of the service delivered: as a result of the influences exerted from the customer side and the shortfalls (gaps) on the part of the service provider. In this case, customer expectations are influenced by the extent of personal needs, word of mouth recommendation and past service experiences.

The model identifies five key discrepancies or gaps relating to managerial perceptions of service quality, and tasks associated with service delivery to customers. The first four gaps (Gap1, Gap2, Gap3, Gap4) are identified as functions of the way in which service is delivered, whereas Gap 5 pertains to the customer and as such is considered to be the true measure of service quality. The present study takes this model as the basis of study. The principal focus of the present study is on Gap 1, Gap 5 and two additional gaps i.e Gap 6(Internal Evaluation Gap i.e. gap between employees' perceptions of customers' expectations and employees' own perceptions with respect to quality of service) and Gap 7 (Delivery Gap i.e. gap between employees' perceptions and customers' perceptions with respect to quality of service). The study measures all these gaps of service quality in order to have a deep understanding of what managers and employees of both the sectors are actually doing for providing quality service in terms of judging customers' expectations, designing the service accordingly and further delivering and communicating the service.

\section{Purpose OF THE STUdY}

The purpose of the study was therefore to analyze the level of service quality of Post office Saving Bank from the perspectives of both customers and employees. The specific objectives of the study were to:

1. Identify the gap between perceptions and expectations of customers with respect to quality of service.

2. Identify the gap between employees' perceptions of customers' expectations and customers' actual expectations with respect to quality of service. 
3. Identify the gap between employees' perceptions of customers' expectations and employees' own perceptions with respect to quality of service.

4. Identify the gap between employees' perceptions and customers' perceptions with respect to quality of service.

\section{METHODOLOGY}

The relevant literature and instruments developed by past studies provided the base for assessing service quality perceptions and expectations of customers. Present study besides adopting the original SERVQUAL model developed by PZB(1988), adds some more statements in order to have more comprehensive and sector specific measure of service quality. The new statements were derived through reviewing of literature and personal interviews with managers, employees and customers of the particular sector. So in total, 35 statements were formed as the basis of measurement of service quality. Measurement instrument of the study is a questionnaire based on SERVQUAL . It consists of 3 parts: First Part deals with demographic profile of customers consisting Name, age, Marital status, Income, qualification etc. Second part of the questionnaire is 'Expectations Section' which consists 35 statements of service quality regarding what customer expects from an excellent post office regarding banking service with responses ranging from 'Strongly Agree'(5) to 'Strongly Disagree'(1) on a five-point Likert scale. Third part of the questionnaire is 'Perception Section' consisting same 35 statements which tend to measure what customer actually believes about the service quality. The target population of the survey was all the saving scheme users of Post Office saving Bank in Punjab state and all the employees working in POSB. The sample size was restricted to 200 customers and 100 employees. For the purpose, 'Simple random sampling' was employed and data has been collected from various branches of India Post across Punjab.

\section{ANALYSIS AND RESULTS}

\section{Demographic profile of customers and employees}

Out of 200 customers of POSB, 50 customers are under the age of 30 years, 128 customers are below 30-45 years, 20 customers lie between the age group 45-60 and one customer above age of 60 . The table reflects that majority of the customers are upto the age of 45 years. Regarding educational profile, 49 (24.5 percent) customers are below graduate, $117(58.5)$ are graduate, 33(16.5) are post-graduate while rest 0.5 percent is doctorate. Data includes $51(25.5 \%)$ business class \& $109(54.5 \%)$ service class. Rest $23(11.5 \%)$ are homemakers and $15(7.5 \%)$ students and only $2(1 \%)$ customers is professional. Majority $(56.5 \%)$ of respondents of POSB fall under income between $20000-40000.28 \%$ of POSB fall under income of Rs 20000, $13 \%$ fall under income group of $40000-60000 \& 2.5 \%$ of POSB customers fall under income group of . 60000-80000. In POSB, majority of the respondents are having saving account i.e $24 \%$ while $11.5 \%$ have current a/c , $14 \%$ have Fixed Deposit , 35\% have Recurring Deposit, 7\% are Monthly Income Scheme users and $3 \& 5.5 \%$ are Senior Citizen Saving Scheme users \& Public Provident Fund customers. It has been observed that majority of the customers invest for maximization of their wealth i.e. $72.5 \%$ whereas $17 \%$ of customers invest for tax saving and $6 \%, .5 \%, 1.5 \%, 2.5 \%$ invest for return, insurance, requirement of business and risk coverage.

The sample of employees contained slightly more males $(57 \%)$ than females (43\%). Regarding mode of employment, the study shows that all the employees under study(100\%) are on regular basis. The respondents ranged from Postal assistant to Senior post Master. About $86 \%$ employees are Postal assistant, $2 \%$ Office Assistant, 10\% Senior Post Master and $2 \%$ Assistant Post Master.

\section{Service Quality Gap analysis}

In the upcoming section, Analysis of all the gaps taken under study is presented. Independent Sample T-Test is used for measuring all the mean differences.

Table- I: Gap mean differences between customers' perceptions and expectations of service quality

\begin{tabular}{|l|l|l|l|l|l|}
\hline Attributes & $\begin{array}{l}\text { Perceptions } \\
\text { Mean }\end{array}$ & $\begin{array}{l}\text { Expectations } \\
\text { Mean }\end{array}$ & $\begin{array}{l}\text { Gap } \\
\text { (Per.-Exp.) }\end{array}$ & T-Value & $\begin{array}{l}\text { Significance } \\
\text { Level. }\end{array}$ \\
\hline Modern Equipment\& Latest Technology & 3.50 & 4.47 & -.97 & -.12 .051 & .000 \\
\hline Visually appealing Infrastructure & 3.84 & 4.28 & -.44 & -7.046 & .000 \\
\hline $\begin{array}{l}\text { Appearance of employees Smart \& } \\
\text { Attractive }\end{array}$ & 3.99 & 4.35 & -.36 & -8.616 & .000 \\
\hline $\begin{array}{l}\text { Material associated with service visually } \\
\text { appealing }\end{array}$ & 3.37 & 4.33 & -.96 & -13.494 & .000 \\
\hline $\begin{array}{l}\text { Service at the time when promised to do } \\
\text { so }\end{array}$ & 4.46 & 4.68 & -.22 & -3.096 & .000 \\
\hline $\begin{array}{l}\text { Sincere Interest to solve problem of } \\
\text { customer }\end{array}$ & 2.38 & 4.69 & -2.31 & -31.077 & .000 \\
\hline Right Service at first instance & 2.18 & 4.71 & -2.52 & -37.002 & .000 \\
\hline Error- free records & 2.17 & 4.72 & -2.55 & -37.982 & .000 \\
\hline Prompt Service to customers & 3.97 & 4.64 & -.675 & -15.695 & .000 \\
\hline Feel Delighted to help customer & 4.01 & 4.56 & -.550 & -13.184 & .000 \\
\hline $\begin{array}{l}\text { Always willing to respond need of } \\
\text { customers }\end{array}$ & 4 & 4.36 & -.36 & -8.459 & .000 \\
\hline
\end{tabular}




\begin{tabular}{|l|l|l|l|l|l|}
\hline Individual attention to customers & 3.83 & 4.69 & -.86 & -14.450 & .000 \\
\hline $\begin{array}{l}\text { Behaviour of employees will instill level } \\
\text { of confidence in customers }\end{array}$ & 3.68 & 4.67 & -.985 & -12.863 & .000 \\
\hline Customers feel fair \& safe in dealing & 3.05 & 4.70 & -1.65 & -20.202 & .000 \\
\hline Professionally competent Employees & 3.09 & 4.73 & -1.635 & -19.755 & .000 \\
\hline Goodwill \& Sound financial foundation & 3.93 & 4.70 & -.770 & -15.437 & .000 \\
\hline Courteous Nature of Employees & 2.55 & 4.12 & -1.57 & -21.925 & .000 \\
\hline Convenient operating Hours & 2.27 & 4.09 & -1.81 & -30.148 & .060 \\
\hline $\begin{array}{l}\text { Detailed presentation of products to } \\
\text { customers }\end{array}$ & 2.90 & 4.36 & -1.460 & -17.874 & .000 \\
\hline Commitment to ethical behaviour & 3.97 & 4.69 & -.72 & -17.512 & .000 \\
\hline Secure SMS alert system & 4.01 & 4.54 & -.52 & -13.234 & .000 \\
\hline Highly Competitive Int. Rates & 4.02 & 4.61 & -.59 & -15.00 & .000 \\
\hline Reasonable Service Charges & 4.01 & 4.77 & -.76 & -21.06 & .000 \\
\hline Easy formalities & 3.19 & 4.51 & -1.31 & -15.984 & .000 \\
\hline Simplified procedure for alterations & 2.39 & 4.45 & -2.05 & -30.282 & .000 \\
\hline Easy Account Enquiries & 2.54 & 4.37 & -1.83 & -24.21 & .000 \\
\hline Communication easy to understand & 3.61 & 4.42 & -.81 & -13.00 & .000 \\
\hline Display of schemes & 2.90 & 4.46 & -1.56 & -19.09 & .000 \\
\hline $\begin{array}{l}\text { Sufficient no. of branches in urban as } \\
\text { well as rural area }\end{array}$ & 2.56 & 4.46 & -1.89 & -24.883 & .000 \\
\hline $\begin{array}{l}\text { Organise consumer } \\
\text { programmes awareness }\end{array}$ & 3.97 & 4.64 & -.67 & -.67 & .000 \\
\hline Sufficient Cash Counters for fast service. & 3.48 & 4.65 & -1.17 & -1.17 & .000 \\
\hline Attractive website with latest information & 3.76 & 4.64 & -.885 & -.885 & .000 \\
\hline $\begin{array}{l}\text { Use of latest internet based } \\
\text { communication tools }\end{array}$ & 3.79 & 4.61 & -.815 & -.815 & .000 \\
\hline Offering easy modes for payment & 4.09 & 4.61 & -.52 & -.52 & .000 \\
\hline $\begin{array}{l}\text { Immediately update services when } \\
\text { required }\end{array}$ & 4.41 & 4.69 & -.27 & -.27 & .000 \\
\hline Nat-estwo-tallpon & \\
\hline
\end{tabular}

Notes: t-test two-tail probability <.05; A negative gap indicates that customers perceived that service delivery did not meet their expectations; a positive gap indicates that tourists perceived that service delivery exceeded their expectations.

\section{Service Quality Gap (Gap 5)}

As noted in Table 1,34 of the 35 attributes showed statistically significant gaps. Only one item'convenient operating hours' (Sig .060) showed insignificant difference. The results indicated that for the most part, customers' expectations are much higher than their actual perceptions regarding service quality. The biggest gaps were on attributes 'error free records' (-2.55), 'right service at first instance' (-2.55), 'Sincere Interest to solve customers' problems' (-2.32), 'Simplified procedures for alterations' (-2.05). Those attributes were found to be the most serious service shortfalls and definitely requires efforts by top management for improvement. The service quality gap also indicates that there were problems in understanding expectations of customers, making service standards and delivering service which collectively became the reason of this gap. Overall, this gap indicates that service quality provided by post office saving bank fell below customers' expectations.

Table-II: Gap mean differences between employees' perceptions of customers' expectations and customers' actual expectations of service quality

\begin{tabular}{|l|l|l|l|l|l|}
\hline \multicolumn{1}{|c|}{ Attributes } & $\begin{array}{l}\text { Employees' perceptions } \\
\text { of } \\
\text { expectations }\end{array}$ & $\begin{array}{l}\text { Customers } \\
\text { Customers, } \\
\text { expectations }\end{array}$ & $\begin{array}{l}\text { Gap } \\
\text { (P-E) }\end{array}$ & T-Value & Sig. \\
\hline Modern Equipment\& Latest Technology & 4.12 & 4.47 & -.35 & -4.924 & .000 \\
\hline Visually appealing Infrastructure & 4.09 & 4.28 & -.19 & -2.468 & .014 \\
\hline Appearance of employees Smart \& Attractive & 4.21 & 4.35 & -.14 & -2.358 & .019 \\
\hline $\begin{array}{l}\text { Material associated with service visually } \\
\text { appealing }\end{array}$ & 4.20 & 4.33 & -.13 & -2.318 & .021 \\
\hline Service at the time when promised to do so & 4.11 & 4.68 & -.57 & -8.436 & .002 \\
\hline Sincere Interest to solve problem of customer & 4.14 & 4.69 & -.55 & -7.501 & .000 \\
\hline Right Service at first instance & 4.71 & -.62 & -9.458 & .000 \\
\hline
\end{tabular}




\begin{tabular}{|l|l|l|l|l|l|}
\hline Error- free records & 4.08 & 4.72 & -.64 & -11.297 & .000 \\
\hline Prompt Service to customers & 4.20 & 4.64 & -.44 & -6.85 & .000 \\
\hline Feel Delighted to help customer & 4.22 & 4.56 & -.34 & -5.19 & .000 \\
\hline Always willing to respond need of customers & 4.28 & 4.36 & -.080 & -1.289 & .199 \\
\hline Individual attention to customers & 4.32 & 4.69 & -.37 & -5.630 & .000 \\
\hline $\begin{array}{l}\text { Behaviour of employees will instill level of } \\
\text { confidence in customers }\end{array}$ & 4.23 & 4.67 & -.44 & -5.810 & .000 \\
\hline Customers feel fair \& safe in dealing & 4.04 & & & \\
\hline Professionally competent Employees & 4.13 & 4.70 & -.66 & -9.707 & .000 \\
\hline Goodwill \& Sound financial foundation & 4.28 & 4.73 & -.60 & -9.412 & .000 \\
\hline Courteous Nature of Employees & 4.47 & 4.70 & -.42 & -6.612 & .000 \\
\hline Convenient operating Hours & 4.45 & 4.12 & .35 & 5.901 & .000 \\
\hline Detailed presentation of products to customers & 4.47 & 4.09 & .36 & 5.608 & .000 \\
\hline Commitment to ethical behaviour & 4.21 & 4.36 & .11 & 1.450 & .149 \\
\hline Secure SMS alert system & 4.22 & 4.69 & -.48 & -7.692 & .000 \\
\hline Highly Competitive Int. Rates & 4.19 & 4.54 & -.32 & -5.671 & .000 \\
\hline Reasonable Service Charges & 4.20 & 4.61 & -.42 & -7.196 & .000 \\
\hline Easy formalities & 4.28 & 4.77 & -.57 & -10.221 & .000 \\
\hline Simplified procedure for alterations & 4.34 & 4.51 & -.23 & -3.528 & .001 \\
\hline Easy Account Enquiries & 4.40 & 4.45 & -.11 & -1.736 & .084 \\
\hline Communication easy to understand & 4.58 & 4.37 & .030 & .366 & .715 \\
\hline Display of schemes & 4.68 & 4.42 & .160 & 2.198 & .029 \\
\hline $\begin{array}{l}\text { Sufficient no. of branches in urban as well as } \\
\text { rural area }\end{array}$ & 4.46 & 4.46 & .220 & 3.456 & .001 \\
\hline Organise consumer awareness programmes & 4.09 & 4.46 & .040 & .606 & .545 \\
\hline Sufficient Cash Counters for fast service. & 4.09 & 4.64 & -.55 & -9.327 & .000 \\
\hline Attractive website with latest information & 4.09 & 4.65 & -.56 & -8.844 & .000 \\
\hline Use of latest internet based communication tools & 3.96 & 4.64 & -.55 & -8.008 & .000 \\
\hline Offering easy modes for payment & 4.04 & 4.61 & -.65 & -9.228 & .000 \\
\hline Immediately update services when required & 4.14 & 4.61 & -.57 & -8.381 & .000 \\
\hline
\end{tabular}

Notes: t-test two-tail probability <.05; A negative gap indicates that employees underestimated customers' expectations; a positive gap indicates that employees overestimated customers' expectations.

\section{Understanding Gap (Gap 1)}

The results of table 2 showed that, for 7 of 35 attributes employees believed that customers' expect more than the customers themselves expect indicating as those items had positive differences whereas 28 items showed negative scores and of those 26 items have significant differences indicating that for those 26 items, employees lacked understanding of customers' expectations. However, for attributes which showed significant positive servqual scores ' Easy account enquiries', 'communication easy to understand', 'Courteous nature of employees', it can be said that employees has a good understanding of customers' expectations. Overall, POSB needs to understand properly what customers expect regarding those 26 items but with special emphasis on 'Use of internet based tools', 'error-free records', 'Right service at first instance' as these items showed biggest gaps.

Table-III: Difference between employees' perceptions of customer expectations and employees' perceptions of their level of service delivery

\begin{tabular}{|l|l|l|l|l|l|}
\hline \multicolumn{1}{|c|}{ Attributes } & $\begin{array}{l}\text { Employees' } \\
\text { perceptions }\end{array}$ & $\begin{array}{l}\text { Employees' Perceptions } \\
\text { of customers' expectations }\end{array}$ & $\begin{array}{l}\text { Gap } \\
\text { (P-E) }\end{array}$ & T-Value & Sig. \\
\hline Modern Equipment\& Latest Technology & 3.84 & 4.12 & -.28 & -3.538 & .001 \\
\hline Visually appealing Infrastructure & 3.85 & 4.09 & -.24 & -2.876 & .004 \\
\hline $\begin{array}{l}\text { Appearance of employees Smart \& } \\
\text { Attractive }\end{array}$ & 3.91 & 4.21 & -.30 & -4.461 & .000 \\
\hline $\begin{array}{l}\text { Material associated with service visually } \\
\text { appealing }\end{array}$ & 3.95 & 4.20 & -.25 & -3.638 & .000 \\
\hline $\begin{array}{l}\text { Service at the time when promised to do } \\
\text { so }\end{array}$ & 4.21 & 4.11 & .10 & 1.203 & .230 \\
\hline $\begin{array}{l}\text { Sincere Interest to solve problem of } \\
\text { customer }\end{array}$ & 4.06 & 4.14 & -.08 & -.87 & .385 \\
\hline Right Service at first instance & 3.96 & 4.09 & -.13 & -1.293 & .198 \\
\hline
\end{tabular}




\begin{tabular}{|l|l|l|l|l|l|}
\hline Error- free records & 3.76 & 4.08 & -.32 & -3.256 & .001 \\
\hline Prompt Service to customers & 4.13 & 4.20 & -.07 & -.972 & .332 \\
\hline Feel Delighted to help customer & 4.18 & 4.22 & -.04 & -.587 & .558 \\
\hline $\begin{array}{l}\text { Always willing to respond need of } \\
\text { customers }\end{array}$ & 4.10 & 4.28 & -.18 & -2.665 & .008 \\
\hline Individual attention to customers & 4.11 & 4.32 & -.21 & -2.910 & .004 \\
\hline $\begin{array}{l}\text { Behaviour of employees will instill level } \\
\text { of confidence in customers }\end{array}$ & 3.90 & 4.23 & -.33 & -3.410 & .001 \\
\hline Customers feel fair \& safe in dealing & 3.94 & 4.04 & -.10 & -1.145 & .253 \\
\hline Professionally competent Employees & 3.68 & 4.13 & -.45 & -5.311 & .000 \\
\hline Goodwill \& Sound financial foundation & 3.77 & 4.28 & -.51 & -6.558 & .000 \\
\hline Courteous Nature of Employees & 4.15 & 4.47 & -.32 & -4.430 & .000 \\
\hline Convenient operating Hours & 4.13 & 4.45 & -.32 & -4.413 & .000 \\
\hline $\begin{array}{l}\text { Detailed presentation of products to } \\
\text { customers }\end{array}$ & 4.11 & 4.47 & -.36 & -4.386 & .000 \\
\hline Commitment to ethical behaviour & 3.79 & 4.21 & -.42 & -4.820 & .000 \\
\hline Secure SMS alert system & 4.20 & 4.22 & -.20 & -.303 & .762 \\
\hline Highly Competitive Int. Rates & 4.26 & 4.19 & -.070 & 1.043 & .298 \\
\hline Reasonable Service Charges & 4.23 & 4.20 & -.030 & .097 & .695 \\
\hline Easy formalities & 4.04 & 4.28 & -.24 & -2.985 & .003 \\
\hline Simplified procedure for alterations & 4.15 & 4.34 & --.19 & -2.877 & .004 \\
\hline Easy Account Enquiries & 4.08 & 4.40 & -.32 & -4.359 & .000 \\
\hline Communication easy to understand & 4.00 & 4.58 & -.58 & -6.980 & .000 \\
\hline Display of schemes & 4.10 & 4.68 & -.58 & -7.799 & .000 \\
\hline $\begin{array}{l}\text { Sufficient no. of branches in urban as } \\
\text { well as rural area }\end{array}$ & 4.19 & 4.50 & -.31 & -4.037 & .000 \\
\hline $\begin{array}{l}\text { Organise consumer } \\
\text { programmes }\end{array}$ & 4.19 & 4.09 & .10 & 1.507 & .133 \\
\hline Sufficient Cash Counters for fast service. & 4.15 & 4.09 & .060 & .820 & .413 \\
\hline $\begin{array}{l}\text { Attractive website with latest } \\
\text { information }\end{array}$ & 4.20 & 4.09 & .110 & 1.545 & .124 \\
\hline $\begin{array}{l}\text { Use of latest internet based } \\
\text { communication tools }\end{array}$ & 4.07 & 3.96 & .110 & 1.433 & .153 \\
\hline Offering easy modes for payment & 4.00 & 4.04 & -.040 & -.415 & .678 \\
\hline $\begin{array}{l}\text { Immediately update services when } \\
\text { required }\end{array}$ & 4.24 & 4.14 & .10 & 1.282 & .202 \\
\hline
\end{tabular}

Notes: t-test two-tail probability<.05; A negative gap indicates that employees believed their service did not meet customers' expectations; a positive gap indicates that employees perceived that their service delivery exceeded customers' expectations.

\section{Internal Evaluation Gap (Gap 6)}

This gap helps management to identify and improve those areas where faulty standards have been set. Results of Table 3 shows that 29 items have been found with negative differences and out of 29 attributes, 20 have significant differences indicating that for these 20 items management is not perceiving more of service quality than they actually perceived about customers' expectations regarding service quality. However, It can be noticed that differences are not too high. Therefore management needs to work a little more regarding evaluating the customers' expectations and to make service standards accordingly. Only two attributes 'communication easy to understand' (-.58, Sig..000) and 'Display of Schemes' which showed bigger gaps (-.58, Sig..000), rest of the attributes have been found with differences of even less than .050 .

Table-IV: Difference between employees' perceptions of their service delivery and customers' perceptions of service quality

\begin{tabular}{|c|l|l|l|l|l|}
\hline \multicolumn{1}{|c|}{ Attributes } & $\begin{array}{l}\text { Customers' } \\
\text { perceptions }\end{array}$ & $\begin{array}{l}\text { Employees' } \\
\text { Perceptions }\end{array}$ & $\begin{array}{l}\text { Gap } \\
\text { perceptions-Employees' } \\
\text { perceptions) }\end{array}$ & T-Value & Sig. \\
\hline Modern Equipment\& Latest Technology & 3.50 & 3.84 & -.34 & -3.857 & .000 \\
\hline Visually appealing Infrastructure & 3.84 & 3.85 & -.01 & -.138 & .890 \\
\hline $\begin{array}{l}\text { Appearance of employees Smart \& } \\
\text { Attractive }\end{array}$ & 3.99 & 3.91 & .080 & 1.527 & .129 \\
\hline
\end{tabular}




\begin{tabular}{|c|c|c|c|c|c|}
\hline $\begin{array}{l}\text { Material associated with service visually } \\
\text { appealing }\end{array}$ & 3.37 & 3.95 & -.58 & -7.192 & .000 \\
\hline $\begin{array}{l}\text { Service at the time when promised to do } \\
\text { so }\end{array}$ & 4.46 & 4.21 & .25 & 2.722 & .007 \\
\hline $\begin{array}{l}\text { Sincere Interest to solve problem of } \\
\text { customer }\end{array}$ & 2.38 & 4.06 & -1.68 & -18.323 & .000 \\
\hline Right Service at first instance & 2.18 & 3.96 & -1.78 & -17.691 & .000 \\
\hline Error- free records & 2.17 & 3.76 & -1.59 & -15.214 & .000 \\
\hline Prompt Service to customers & 3.97 & 4.13 & -.16 & -3.022 & .003 \\
\hline Feel Delighted to help customer & 4.01 & 4.18 & -.17 & -3.715 & .000 \\
\hline $\begin{array}{l}\text { Always willing to respond need of } \\
\text { customers }\end{array}$ & 4.00 & 4.10 & -.10 & -1.991 & .048 \\
\hline Individual attention to customers & 3.83 & 4.11 & -.28 & -3.833 & .000 \\
\hline $\begin{array}{l}\text { Behaviour of employees will instill level } \\
\text { of confidence in customers }\end{array}$ & 3.68 & 3.90 & -.22 & -2.081 & .038 \\
\hline Customers feel fair \& safe in dealing & 3.05 & 3.94 & -.89 & -9.050 & .000 \\
\hline Professionally competent Employees & 3.09 & 3.68 & -.59 & -5.822 & .000 \\
\hline Goodwill \& Sound financial foundation & 3.93 & 3.77 & .16 & 2.265 & .025 \\
\hline Courteous Nature of Employees & 2.55 & 4.15 & -1.60 & -19.177 & .000 \\
\hline Convenient operating Hours & 2.27 & 4.13 & -1.86 & -26.880 & .000 \\
\hline $\begin{array}{l}\text { Detailed presentation of products to } \\
\text { customers }\end{array}$ & 2.90 & 4.11 & -1.21 & -13.336 & .000 \\
\hline Commitment to ethical behaviour & 3.97 & 3.79 & .18 & 3.161 & .002 \\
\hline Secure SMS alert system & 4.01 & 4.20 & -.19 & -3.528 & .001 \\
\hline Highly Competitive Int. Rates & 4.02 & 4.26 & -.24 & -4.665 & .000 \\
\hline Reasonable Service Charges & 4.01 & 4.23 & -.22 & -3.520 & .001 \\
\hline Easy formalities & 3.19 & 4.04 & -.85 & -8.916 & .000 \\
\hline Simplified procedure for alterations & 2.39 & 4.15 & -1.76 & -24.934 & .000 \\
\hline Easy Account Enquiries & 2.54 & 4.08 & -1.54 & -18.436 & .000 \\
\hline Communication easy to understand & 3.61 & 4.00 & -.39 & -5.268 & .000 \\
\hline Display of schemes & 2.90 & 4.10 & -1.20 & -13.288 & .000 \\
\hline $\begin{array}{l}\text { Sufficient no. of branches in urban as } \\
\text { well as rural area }\end{array}$ & 2.56 & 4.19 & -1.63 & -19.194 & .000 \\
\hline $\begin{array}{lll}\begin{array}{l}\text { Organise } \\
\text { programmes }\end{array} & \text { consumer } & \text { awareness } \\
\end{array}$ & 3.97 & 4.19 & -.22 & -3.966 & .000 \\
\hline Sufficient Cash Counters for fast service. & 3.48 & 4.15 & -.67 & -7.992 & .000 \\
\hline Attractive website with latest information & 3.76 & 4.20 & -.44 & -6.563 & .000 \\
\hline $\begin{array}{lccc}\text { Use of latest } & \text { internet } & \text { based } \\
\text { communication tools } & & \\
\end{array}$ & 3.79 & 4.07 & -.28 & -3.310 & .001 \\
\hline Offering easy modes for payment & 4.09 & 4.00 & .09 & 1.331 & .184 \\
\hline $\begin{array}{lll}\begin{array}{l}\text { Immediately update } \\
\text { required }\end{array} & \text { services } & \text { when } \\
\end{array}$ & 4.41 & 4.24 & .17 & 2.573 & .011 \\
\hline
\end{tabular}

Notes: t-test two-tail probability <.05; A negative gap indicates that employees overestimated their service delivery in meeting customers' expectations; a positive gap indicates that employees underestimated their service delivery in meeting customers' expectations

\section{Service Delivery Gap (Gap 7)}

Table 4 clearly shows that 29 out of 35 attributes have negative gaps and except one attribute 'visually appealing infrastructure', all the items have significant differences. All these differences indicate shortfall in service delivery causing overall service quality gap. For these items, Customers' perceptions are found less as compared to what employees' perceive about service delivery. Further, it can be noted that bigger gaps are found in case of 'Convenient operating hours' (-1.86), 'Right service at first instance' (-1.78) and 'Simplified procedures for alterations'(-.1.76)., Overall, it can be said that for improving service quality, top management has to work on these areas of service delivery shortfalls and employees should be trained enough to deliver the service according to established standards.

\section{FINDINGS AND RESULTS}

Present study developed a model of various service quality gaps i.e. Understanding Gap, Internal Evaluation Gap, Service Delivery Gap which caused major service quality gap. The sector under study showed negative scores for most of the attributes seeking attention of top management. Furthermore, by studying all the gaps, the study also highlighted areas where the actual problem existed. As found in study for these 3 attributes 'Easy account enquiries', 'Communication easy to understand', 'Courteous nature of employees', employees had good understanding of 
customers' expectations but while evaluating internally and making standards, gaps regarding these items turned negative which were earlier positive. So, the study provides useful information which correlates all these factors to improve service performance. Finally, the research highlighted the areas of deficiencies where there is need of improvement.

This study will definitely be useful for service providers to ascertain the factors considered important by customers pertaining to service quality. It has also pinpointed areas where managers need more attention. As found in the study, to improve its service quality level, POSB must focus on giving reliable service and it must work on updating the services as and when required. To improve understanding gap, POSB should organize programmes and surveys to understand customers' expectations properly. Employees should be trained enough to make right service standards and to interact with customers to improve service delivery.

\section{CONCLUSION AND FUTURE SCOPE OF RESEARCH}

The present study has worked on many issues that are important to any service industry. To sustain in this global era, where large number of competitors are there around the world, every organisation needs to understand deeply the concept of 'service quality' and conduct surveys from time to time to retain the existing customers and enhance the customer base. Though study emphasized to cover each and every aspect on customers' and employees' perceptions and expectations regarding service quality. However, there still remains viable prospects for future. For this, the study provides a number of directions for future research as follows:

- SERVQUAL and SERVPERF are two major tools for assessing service quality level. Present study uses Servqual model developed by PZB(1988) with some modifications. However, SERVPERF can also be used for assessing service quality level for studies in future. Study can also be undertaken by using and comparing both models as to know which one is superior.

- Future research can also extend to develop a richer model that will have other attributes also beyond the 35 used in this study.

- The present research focuses on service quality perceptions of customers of state of Punjab Only. Research can be carried out in other states of India as well. Comparative inter-state service quality can also be analyzed.

\section{REFERENCES}

1. Aggarwal, R. (2012). Identifying Factors Influencing Preference Towards Post Office Saving Schemes. International Journal of Research in Management and Technology. 2 (6), 550-559.

2. Asubonteg,P., Mccleary.K.J., Swan.J.E. (1996). SERVQUAL Revisited:a critical review of service . Journal of services marketing. 10(6), 62-81.

3. Azizzadeh, F., Khalili, K., \& Soltani, I. (2013). Service quality measurement in the public sector. International Journal of Economics, Finance and Management , 2 (1), 114-121.

4. Brady, M. K., \& Cronin Jr, J. J. (2001). Some new thoughts on conceptualizing perceived Service quality. The Journal of Marketing, 65 (3), 34-49.

5. Brown S. W., Swartz. T. A. (1989). A Gap Analysis of Professional Service Quality. Journal of Marketing, 53(2), 92-98.
6. Campos, D. F., \& Marodin, T. G. (2012). Perceptions of Quality and Expectations of Hotel Services. Journal of Operations and Supply chain Management , 5 (1), 82-99.

7. Cronin Jr, J. J., \& Taylor, S. A. (1992). Measuring Service Quality : A Reexamination and Extension. Journal of Marketing, 56 (3), 55-68.

8. Cronin Jr, J. J., \& Taylor, S. A. (1994).SERVPERF Versus SERVQUAL: Reconciling Performance-Based and Perceptions-Minus-Expectations Measurement of Service Quality.Journal of marketing. 58(1),125-131.

9. Dotchin, J. A., \& Oakland, J. S. (1994). Total Quality Management In Services: Part 3: Distinguishing Perceptions of Service Quality. International Journal of Quality and Reliability Management , 11 (4), 6-28.

10. Edvardsson.B.,Scheuing.E.E.(1994).Service Integrity. Managing Service Quality:An International journal.4(4).24-31.

11. Gronroos.C.(1984). A Service Quality Model and its Marketing Implications. European Journal of Marketing, 18(4), 36-44.

12. Handrinos.M.C.,Folinas.D.,Rotsios.K.(2015).Using the servqual model to evaluate the quality of services for a farm school store.Journal of marketing and consumer behaviour in emerzing markets.1(1),62-74.

13. Hsiao, C. T., \& Lin, J. S. (2008). A Study of service quality in Public Sector. International journal of Electronic Business Management , 6 (1), 29-37.

14. Hu, H. Y., Cheng, C. C., Chiu, I. S., \& Hong, Y. F. (2011). A study of Customer Satisfaction, Customer Loyality and quality attributes in Taiwan' $\mathrm{s}$ medical service industry. African Journal of Business Management , 5 (1), 187-195.

15. Kanthi, K. P., \& Kumar, M. A. (2013). Post Office savings and its Relevance in rural reas. International Journal of scientific Research , 2 (1), 27-30

16. Kumar, A., \& Dash, M. K. (2013). Constructing a Measurement In service quality for Indian Banks : Structural Equation Modeling Approach. Journal of Internet Banking and Commerce , 18 (1), 1-13.

17. Lewis, B. R., \& Mitchell, V. W. (1990). Defining and Measuring the Quality of customer Service. Marketing Intelligence and Planning , 18 (6), 11-17.

18. Mukherjee, A., Nath, P., \& Pal, M. (2003). Resourece, Service Quality and Performance Triad. The Journal of the Operational Research Society , 54 (7), 723-735.

19. Parasuraman, A., Zeithaml, V. A., \& Berry, L. L. 1985).A conceptual model of service quality and its implications for future research.Journal of marketing. Vol.49.41-50.

20. Parasuraman, A., Zeithaml, V. A., \& Berry, L. L. (1988). SERVQUAL: A Multiple-Item Scale For Measuring Consumer Perceptions of Service Quality. Journal of Retailing , 64, 12-40

21. Parasuraman, A., Zeithaml, V. A., \& Berry, L. L. (1991).Perceived Service Quality as a customer-based performance measure: An empirical examination of organisational barriers using an extended service quality model. Human Resource Management.30(3),335-364.

22. Parasuraman, A., Zeithaml, V. A., \& Berry, L. L. (1994). Reassessment of Expectations as a comparison standard in measuring service quality: Implications for future research. Journal of Marketing. Vol.58,111-124.

23. Patterson, P. G., \& Johnson, L. W. (1993). Disconfirmation of Expectations and The Gap Model of Service Quality : An Integrated Paradigm. Journal of Consumer Satisfaction, Dissatisfaction and Complaining Behavior, 6, 90-99.

24. Randheer, K., AL- Motawa, A. A., \& J, P. V. (2011). Measuring Commuters' Perception on Service quality using SERVQUAL in Public Transportation. International Journal of Marketing Studies , 3 (1), 21-27.

25. Renganathan, R., Balachandran, S., \& Govindarajan, K. (2012). Customer perception towards banking sector: Structural Equation Modeling aaproach . African journal of Business Management , 6 (46), 11426-11436.

26. Rust.R.T., \& Oliver.R.L.(1994. "Service Quality:Insights and managerial implications from the frontier".In Rust.R.T.,Oliver.R.L.(Eds),Service Quality: New directions in theory and practice,Sage Publications, Thousand oaks,pp1-19.

27. Saraswathi, S. (2011). Perception of Customers on the Performance of Private Banks. International Journal of Management and Business Studies. , 1 (3), 95-99. 
28. Seth N., S. G. D., \& Vrat P. (2005). Service quality models: a review .International Journal of Quality \& Reliability Management.22(9), 913-949.

29. Tsang, N., \& Qu, H. (2000). Service Quality in China's Hotel Industry : A perspective from Tourists and Hotel Managers. International Journal of Contemporary Hospitality Management , 12 (5), 316-326.

30. Vanpariya,B, Ganguly.P. (2010). SERVQUAL versus SERVPERF: An Assessment from Indian Banking Sector. http://ssrn.com/abstract=1783471

31. Wisniewski.M.,Donnelly.M.(1996).Measuring service quality in the public sector: The potential for servqual. Total quality management and Business Excellence. 7(4),357-365.

32. Wisniewski.M.(2001).Using servqual to assess customer satisfaction with public sector services.Managing setvice quality:An International journal. 11(6).380-386.

33. Witkowski. T. H., Wolfinbarger. M. F. (2002). Comparative service quality: German and American ratings across service settings .Journal of Business Research, 55, 875-881.

34. Yarimoglu, E. K. (2014). A review of dimensions of Service Quality Models. Journal of Marketing Management , 2 (2), 79-93.

35. Zeithamll, V. A., Berry, L. L., \& Parasuraman, A. (1988). Communication and Control Process In the Delivery of Service Quality. Journal of Marketing, 52 (2), 35-48.

36. Zeithmal, A. V., Berry, L. 1., \& Parasuraman, A. (1996). The Behavioral Consequences of Service quality. Journal of Marketing , 60 (2), 31-46 